\title{
ANALISIS PRODUKTIVITAS PENGELOLAAN ZAKAT DARI SISTEM BAGI HASIL (STUDI KRITIS BANK MUAMALAT CABANG KOTA JAYAPURA)
}

\author{
Eko Siswanto \\ IAIN Fattahul Muluk Papua \\ Email: siswantoeko44@yahoo.co.id
}

\begin{abstract}
Abstrak
Kedudukan zakat dalam Islam sangatlah penting dalam rangka menjaga eksistensi Islam dan umat. Begitu seriusnya kedudukan zakat ini, sehingga pada awal kekhalifahan Abu Bakar Ash-Shiddiq yang terdapat orang-orang yang melakukan pembangkangan untuk menunaikan zakat, oleh sebab itu khalifah melakukan ijtihad dengan memerangi mereka. Ini menunjukkan terhadap komitmen Islam dalam menanggulangi kaum dlu'afa secara berkelanjutan dan sistematis. Untuk mengakomodir jumlah kaum dlu'afa yang jumlahnya sangat banyak, pada saat sekarang ini para 'amilin menempuh upaya dengan menyalurkan zakat dalam bentuk produktif. Artikel ini bertujuan untuk menganalisis produktivitas pengelolaan zakat dari sistem bagi hasil pada Bank Muamalat Kota Jayapura. Penelitian dilakukan dalam bentuk yuridis-normatif, selain mengkaji tentang analisa produktivitas pengelolaan zakat dari sistem bagi hasil di Bank Muamalat Kota Jayapura. Adapun pendekatan penelitian yang di gunakan meliputi: pendekatan teologis, pendekatan sosiologis, pendekatan filosofis. Hasil penelitian menunjukkan bahwa sistem bagi hasil (profit sharing) yang digunakan pada Bank Muamalat Cabang Kota Jayapura yaitu akad utama a/musyarakah dan al-mudharabah. Sistem bagi hasil pada Bank Muamalat Cabang Kota Jayapura melalui Baitul Maal Muamalat (BMM) sebatas pembagian sembako untuk kaum dluafa dan anak yatim piatu, program SBL (Sahur Berbuka dan Lebaran) yang diberikan berupa paket sembako tiga ratus ribu rupiah perpaket, dan paket lebaran tiga ratus ribu rupiah peranak berupa uang tunai dan perlengkapan sholat.
\end{abstract}

Kata Kunci: Bank Muamalat, Produktivitas, Zakat

\begin{abstract}
The position of zakat in Islam is very important in order to maintain the existence of Islam and the ummah. So serious is the position of this zakat, so that at the beginning of the Caliphate of Abu Bakr al-Siddiq there were people who carried out defiance to pay zakat, therefore the Caliph carried out ijtihad by fighting them. This shows the commitment of Islam in tackling the poor in a sustainable and systematic manner. To accommodate the large number of dlu'afa people, at the present time the ilin amilin are making efforts by channeling zakat in productive forms. This article aims to analyze the productivity of zakat management from the profit sharing system at Bank Muamalat Kota Jayapura. The study was conducted in a juridicalnormative manner, in addition to reviewing the productivity analysis of zakat management from the profit sharing system at Bank Muamalat Kota Jayapura. The research approaches used include: theological approaches, sociological approaches, philosophical approaches. The results showed that the profit sharing system used at Bank Muamalat Kota Jayapura Branch was the main contract a / -musyarakah and al-mudharabah. The profit sharing system at Bank Muamalat Kota Jayapura Branch through Baitul Maal Muamalat (BMM) was limited to the distribution of basic necessities for the dluafa and orphans, the SBL program (Sahur berbuka and Lebaran) in the form of basic food packages 300.000 rupiahs per package, and Lebaran packages of 300.000 rupiahs in the form of cash and prayer equipment.
\end{abstract}

Key Words: Muamalat Bank, Productivity, Zakat. 


\section{PENDAHULUAN}

Dari beberapa literatur, zakat mempunyai arti suci, berkembang, berkah, tumbuh, bersih dan baik. ${ }^{1}$ Zakat merupakan salah satu rukun Islam yang bersifat ibadah dan sosial, yang kewajibannya sering digandengkan dengan kewajiban shalat. Namun Zakat secara syariah terdapat beberapa definisi zakat yang dikemukakan oleh ulama mazhab, diantaranya adalah sebagai berikut:Ulama mazhab Maliki mendefinisikan zakat adalah mengeluarkan bagian tertentu dari harta tertentu yang telah mencapai satu nisab bagi orang yang berhak menerimanya, dengan ketentuan harta itu milik sempurna, telah haul.Ulama Mazhab Hanafi mendefinisikan zakat adalah pemilikan bagian tertentu yang dimiliki seseorang berdasarkan ketetapan Allah SWT.Ulama Mazhab Syafi'i mendefinisikan zakat adalah sesuatu yang dikeluarkan dari harta atau jiwa dengan cara tertentu.Ulama Mazhab Hambali mendefinisikan zakat adalah hak wajib pada harta tertentu pada waktu yang tertentu pula.

Zakat yang terkumpul bukan hanya untuk ibadah dalam arti memenuhi kebutuhan konsumtif, tapi bisa juga dijadikan sumber pembiayaan. Hal senada juga disampaikan oleh salah seorang pakar ekonomi Islam yaitu Ir. H. Adiwarman Azwar Karim, Ia mengingatkan nilai penting pengelolaan zakat untuk menghasilkan kegiatan ekonomi produktif. Hal serupa juga disampaikan oleh ketua Majelis Perwakilan Ulama Provinsi Nanggroe Aceh Darussalam Muslim Ibrahim dalam acara kajian tingkat tinggi yang diselenggarakan pada tanggal 9 Juni 2007 bertempat di Mesjid raya Banda Aceh dalam makalah beliau yang isinya antara lain: "Kalau sanggup bekerja mencari nafkah dan hampir dapat mencukupi dirinya sendiri dan keluarganya, seperti buruh/tukang, pedagang, petani, dan lain-lain, akan tetapi mereka kekurangan sarana, prasarana ataupun modal. Mereka tidak memperoleh hasil sesuai dengan kebutuhannya. Bagi mereka ini dapat diberi sesuatu, misalnya modal usaha. Diharapkan dengan modal ini, mereka akan dapat hidup layak dan malah dapat menjadi muzakki pada masa-masa yang akan datang.Dengan pola produktif ini, tentunya tidak akan mustahil bahwa zakat dapat mempunyai peranan yang sangat penting dalam membuka lapangan pekerjaan baru, meningkatkan derajat hidup orang-orang miskin yang selalu kekurangan dan meningkatkan tali persaudaraan si kaya dan si miskin.

Landasan awal pengelolaan zakat produktif ini adalah bagaimana dana zakat tidak habis dikonsumsi untuk kebutuhan sehari-hari, tetapi lebih bermakna karena digunakan untuk melancarkan usahanya. Bukankah Nabi Muhammad saw telah mengingatkan kita sebagaimana terdapat dalam hadits

${ }^{1}$ Amiruddin Inoed dkk.Anatomi Fqih Zakat (Yogyakarta: Pustaka Pelajar, 2005), h.46. 
beliau yang diriwayatkan oleh Imam Bukhari: "Tidak ada sesuatu makanan yang lebih baik bagi seseorang, melainkan apa yang dihasilkan dari karya tangannya sendiri." Disamping itu ada pepatah mengatakan, Berikanlah kail, bukan ikannya. Oleh sebab itu, modal usaha yang digulirkan dari dana zakat diharapkan menjadi kail yang mampu menangkap ikan-ikan yang tersedia di alam. Dengan demikian ia akan dapat berusaha sendiri dalam meningkatkan tingkat perekonomiannya sehari-hari.

Konsep dan tujuan zakat secara ideal di atas akan bisa terwujud manakala kesadaran pihak-pihak yang diwajibkan membayar zakat akan komitmen untuk menunaikannya, serta adanya sistem pengelolaan zakat yang baik. Pihak-pihak yang dimaksud tentunya adalah secara personal yang sudah mencapai predikat muzakki. Lantas bagaimana jika kita melihat pihak lain yang bukan personal, namun berupa kelembagaan yang dapat menghasilkan pendapatan besar? Sebut saja beberapa lembaga keuangan syari'ah yang memasarkan produknya dan mendapat laba atau penghasilan besar. Haruskah sebuah kelembagaan keuangan tersebut dikenakan kewajiban mengeluarkan zakatnya? Jika misalnya diwajibkan mengeluarkan zakatnya, pertanyaan berikutnya adalah, bagaimana pola pengelolaan zakatnya supaya dapat bernilai produktif? Salah satu contoh lembaga keuangan syari'ah yang ada di Indonesia adalah Bank Muamalat.

Sebagai salah satu lembaga keuangan syari'ah, Bank Muamalat merupakan perbankan syari'ah yang menerapkan sistem bagi hasil. Dari implementasi sistem bagi hasil tersebut, Bank Muamalat dapat mendapatkan keuntungan. Sehingga tiap tahun dapat memberikan bantuan dan kontribusinya kepada masyarakat yang membutuhkan sebagai zakatnya. Pemberian yang merupakan zakat tersebut bisa dalam bentuk pemberian sembako kepada fakir miskin, bantuan untuk anak sekolah baik berupa uang maupun perlengkapan, serta bantuan untuk tempat-tempat ibadah. Bank Muamalat sebagai lembaga keuangan yang mengatur dan mengelola harta dengan berbagai jenis transaksi yang ada. Sehingga karena di dalamnya memuat harta seseorang, maka tentunya di dalamnya terdapat beberapaa bagian yang harus dikeluarkan sebagai zakat dari harta tersebut.

Secara ideal bahwa harta zakat tersebut didistribusikan kepada pihakpihak yang berhak menerima zakat (muztahiq). Atau bisa juga harta zakat dikelola menjadi suatu harta yang memiliki nilai produktivitas. Karena diharapkan dengan harta zakat mampu meningkatkan taraf hidup masyarakat bagi masyarakat yang masih belum berdaya dari sisi kapasitas ekonominya. Pertanyaan yang muncul adalah, apakah ketika zakat dalam konteks bank muamalat tersebut seyogyanya diperuntukkan bagi mereka yang berhak menerima atau harta zakat tersebut seharusnya dikembangkan untuk menjadi harta yang bernialai produktif? Jika dan zakat di harapkan 
mampu meningkatkan kapasitas ekonomi umat, maka seharusnya dan zakat tersebut dikelola agar dapat bernilai produktif.

Sebagai bahan untuk melakukan telaah pustaka, penulis membandingkan atara judul penulis yakni "Analisa Produktivitas Pengelolaan Zakat Dari Sistem Bagi Hasil" (Studi Kritis Bank Muamalat Kota Jayapura) dengan dua tulisan karya ilmiah berikut ini. Pertama, jurnal yang ditulis oleh Ahmad Mansur al-Wafa dengan judul "Potensi Tabungan, Modal dan Pertumbuhan Ekonomi Dalam perspektif Ekonomi Islam. ${ }^{2}$ Tulisan jurnal ini dititikbertakan pada pembahasan mengenai arti modal dan tabungan sebagai unsur penting dalam proses pertumbuhan ekonomi yang islami yang sarat dengan nilai-nilai moral dan norma-norma agama. Dan juga menjelaskan bahwa dalam sistem ekonomi Islam, modal dan tabungan bisa diakumulasi sedemikian rupa melebihi apa yang bisa diakumulasi dan bahkan iklim investasi dalam sistem ekonomi Islam bisa tercipta sedemikian rupa melebihi apa yang bisa dilakukan dalam sistem ekonomi Islam. Kedua, jurnal yang ditulis oleh Mansur al-Wafa dengan judul "Preferensi Islam terhadap Penghapusan Bunga dalam Membuat Struktur Modal dan Biaya Modal dalam Sistem Keuangan Islam". ${ }^{3}$ Dalam tulisan ini menjelaskan bahwa salah satu dimensi utama dari pasar uang adalah bunga. Bunga merupakan harga dari uang yang digunakan dalam suatu perekonomian. Sulit dibayangkan bagaimana sistem perekonomian kapitalistik berjalan tanpa adanya bunga. Namun demikian, Islam melarang adanya praktek bunga dalam bentuk apapun dalam sistem perekonomian termasuk dalam membuat struktur modal dan biaya penggunaan modal dalam usaha, tetapi tidak menolak adanya time value of money di mana penyedia modal berhak mendapatkan bagi hasil sesuai dengan rasio yang disepakati dan yang telah ditetapkan sebelumnya, dan bukan berdasarkan suku bunga melainkan berupa anticipated but uncertain rate of profit, di mana seseorang dapat berharap mendapatkan keuntungan dari penggunaan modalnya di dalam melakukan bisnis dalam waktu tertentu. Dan juga memuat penjelasan tentang mengapa sistem keuangan Islam menghapuskan bunga dalam membuat struktur modal dan penyertaan modal dalam usaha, baik modal yang berupa ekuitas maupun dana pinjaman.

${ }^{2}$ Ahmad Mansur al-Wafa.Potensi Tabungan, Modal dan Pertumbuhan Ekonomi Dalam perspektif Ekonomi Islam (Surabaya: Program Pascasarjana IAIN Sunan Ampel Surabaya, 2003), 52.

${ }^{3}$ Ahmad Mansur al-Wafa.Preferensi Islam terhadap Penghapusan Bunga dalam Membuat Struktur Modal dan Biaya Modal dalam Sistem Keuangan Islam (Surabaya: Program Pascasarjana IAIN Sunan Ampel Surabaya, 2004), 1. 


\section{METODE}

Penelitian ini merupakan penelitian lapangan (field research) dan penelitian ini bersifat deskriptif, yakni memberikan gambaran dan analisis secara menyeluruh tentang analisa produktivitas pengelolaan zakat dari sistem bagi hasil di Bank Muamalat Cabang Kota Jayapura. Penelitian ini berbentuk yuridis-normatif, selain mengkaji tentang analisa produktivitas pengelolaan zakat dari sistem bagi hasil di Bank Muammalat Cabang Kota Jayapura. Adapun pendekatan penelitian yang di gunakan meliputi: pendekatan teologis, pendekatan sosiologis, pendekatan filosofis dan menjadikan pegawai Bank Muamalat Cabang Kota Jayapura sebagai subjek penelitian. Teknik pengumpulan data menggunakan observasi dan wawancara terhadap informan yang terdiri dari unsur pimpinan dan staf di Bank Muamalat Cabang Kota Jayapura.

Teknik analisis data yang digunakan dalam penelitian ini adalah analisis deskriptif kualitatif yang meliputi: analisis induktif, analisis deduktif, analisis komparatif, dan analisis historis, artinya, bahwa penelitian ini bertujuan untuk memahami dan menemukan generalisasi yang berguna dalam memahami kenyataan sejarah yang dapat digunakan untuk bahan perbandingan antara data yang satu dengan lainnya berdasarkan kondisi Bank Muammalat Cabang Kota Jayapura. ${ }^{4}$

\section{KONSEP BAGI HASIL DI BANK MUAMALAT CABANG KOTA JAYAPURA}

Terdapat beberapa macam sistem bagi hasil (profit sharing) pada Bank Muamalat Cabang Kota Jayapura. Prinsip bagi hasil (profit sharing) merupakan karakteristik umum dan landasan dasar operasional Bank Muamalat secara keseluruhan dan merupakan prinsip dalam perbankan syari'ah yang paling banyak dipakai adalah akad utama a/-musyarakah dan al-mudharabah, sedangkan al-muzaro'ah dan al-musaqoh dipergunakan khusus untuk plantation financing atau pembiayaan oleh beberapa bank Islam. Produk Bank Muamalat yang menggunakan prinsip bagi hasil adalah mudharabah dan musyarakah. Mudharabah adalah kerjasama antara dua pihak atau lebih dimana salah satu pihak menyediakan dana seluruhnya dan pihak lain menjadi pengelola dan apabila terjadi kerugian di tanggung oleh pihak yang mempunyai modal selama kerugian bukan kelalaian atau disengaja oleh pengelola. Musyarakah adalah akad kerjasama antara dua pihak atau lebih untuk usaha tertentu dimana masing-masing pihak memberikan kontribusi dana dengan kesepakatan. Keuntungan dan resiko

${ }^{4}$ Winarno Suharman, Dasar dan Teknik Research (Bandung: Angkasa, 1987), h. 56. 
akan di tanggung bersama sesuai dengan kesepakatan yang ditentukan di awal perjanjian.

Nisbah keuntungan merupakan salah satu rukun yang khas dalam akad mudharabah, yang tidak ada dalam akad jual beli. Nisbah ini mencerminkan imbalan yang berhak diterima oleh kedua belah pihak yang bermudharabah. Mudharib mendapatkan imbalan atas kerjanya, sedangkan shahibal-mal mendapatkan imbalan atas penyertaan modalnya. Nisbah keuntungan inilah yang akan mencegah terjadinya perselisihan antara kedua pihak mengenai cara pembagian keuntungan, adapun nisbah keuntungan harus dinyatakan dalam bentuk prosentase antara kedua belah pihak, bukan dinyatakan dalam nilai nominal tertentu. Penentuan besarnya nisbah ditentukan berdasarkan kesepakatan masing-masing pihak yang berkontrak, tetapi dalam prakteknya di perbankan modern, tawar-menawar nisbah antara pemilik modal (yakni investor atau deposan) dengan bank syari'ah hanya terjadi bagi deposan/investor dengan jumlah besar, karena mereka ini memiliki daya tawar yang relatif tinggi. Kondisi seperti ini sebagai spesial nisbah, sedangkan untuk nasabah deposan kecil tawar-menawar tidak terjadi. Bank syari'ah akan mencantumkan nisbah yang ditawarkan, deposan boleh setuju boleh tidak. Bila setuju maka ia akan melanjutkan menabung, sebaliknya bila tidak setuju dipersilahkan mencari bank syari'ah lain yang menawarkan nisbah lebih menarik.

Dari implementasi sistem bagi hasil yang diterapkan oleh Bank Muamalat sebagai salah satu perbankan syari'ah tersebut, perlu di pahami oleh banyak pihak mengenai perbedaan bagi hasil dengan bunga bank syari'ah berdasarkan pada prinsip profit and loss sharing (bagi untung dan bagi rugi). Bank syari'ah tidak membebankan bunga, melainkan mengajak partisipasi dalam bidang usaha yang didanai. Para deposan juga sama-sama mendapat bagian dari keuntungan bank sesuai dengan rasio yang telah ditetapkan sebelumnya. Dengan demikian ada kemitraan antara bank syari'ah dengan para deposan di satu pihak dan antara bank dan para nasabah investasi sebagai pengelola sumber dana para deposan dalam berbagai usaha produktif di pihak lain. Sistem ini berbeda dengan bank konvensional yang pada intinya meminjam dana dengan membayar bunga pada satu sisi neraca dan memberi pinjaman dana dengan menarik bunga pada sisi lain. Kompleksitas perbankan Islam tampak dari keragaman dan penamaan instrumen-instrumen yang digunakan serta pemahaman dalil-dalil hukum Islamnya.

Bank Muamalat memberikan layanan bebas bunga kepada para nasabahnya, pembayaran dan penarikan bunga dilarang dalam semua bentuk transaksi. Islam melarang kaum muslimin menarik atau membayar bunga(riba). Sumber utama ajaran Islam adalah Al-Qur'an dan al-sunnah. 
Kedua sumber ini menyatakan bahwa penarikan bunga adalah tindakan pemerasan dan tidak adil, sehingga tidak sesuai dengan gagasan Islam tentang keadilan dan hak-hak milik. Pembayaran dan penarikan bunga sebagaimana terjadi dalam sistem perbankan konvensional secara terangterangan dilarang oleh al-Qur'an, sehingga para investor harus diberi kompensasi dengan cara lain. Perbedaan yang mendasar antara sistem keuangan konvensional dengan syari'ah terletak pada mekanisme memperoleh pendapatan, yakni bunga dan bagi hasil. Dalam hukum Islam (fiqh), bagi hasil terdapat dalam mudharabah dan musyarakah. Kedua bentuk perjanjian keuangan itu dianggap dapat menggantikan riba, yang mengambil bentuk bunga. Antara bunga dan bagi hasil, keduanya sama-sama memberikan keuntungan bagi pemilik dana. Namun keduanya mempunyai perbedaan yang sangat nyata. Perbedaan itu dapat dilihat dari tabel berikut:

\begin{tabular}{|l|l|}
\hline \multicolumn{1}{|c|}{ BUNGA } & \multicolumn{1}{c|}{ BAGI HASIL } \\
\hline $\begin{array}{l}\text { Penentuan bunga dibuat pada waktu } \\
\text { ukad dengan asumsi harus selalu }\end{array}$ & $\begin{array}{l}\text { Penentuan besarnya rasio/nisbah } \\
\text { bagi hasil dibuat pada waktu akad } \\
\text { dengan berpedoman pada } \\
\text { kemungkinan untung rugi. }\end{array}$ \\
\hline $\begin{array}{l}\text { Besarnya prosentase berdasarkan } \\
\text { pada jumlah uang (modal) yang } \\
\text { dipinjamkan. }\end{array}$ & $\begin{array}{l}\text { Besarnya rasio bagi hasil } \\
\text { berdasarkan pada jumlah } \\
\text { keuntungan yang diperoleh }\end{array}$ \\
\hline $\begin{array}{l}\text { Pembayaran bunga tetap seperti yang } \\
\text { dijanjikan tanpa pertimbangan } \\
\text { apakah proyek yang dijalankan oleh } \\
\text { pihak nasabah untung atau rugi. }\end{array}$ & $\begin{array}{l}\text { Bagi hasil bergantung pada } \\
\text { keuntungan proyek yang dijalankan } \\
\text { Bila usaha merugi, kerugian akan } \\
\text { ditanggung bersama oleh kedua } \\
\text { belah pihak. }\end{array}$ \\
\hline $\begin{array}{l}\text { Jumlah pembayaran bunga tidak } \\
\text { meningkat sekalipun jumlah } \\
\text { keuntungan berlipat atau keadaan } \\
\text { ekonomi sedang "booming”. }\end{array}$ & $\begin{array}{l}\text { Jumlah pembagian laba meningkat } \\
\text { sesuai } \\
\text { dengan peningkatan jumlah } \\
\text { pendapatan }\end{array}$ \\
\hline $\begin{array}{l}\text { Eksistensi bunga diragukan (kalau } \\
\text { tidak dikecam) oleh semua agama, } \\
\text { termasuk islam. }\end{array}$ & $\begin{array}{l}\text { Tidak ada yang meragukan } \\
\text { keabsahan } \\
\text { bagi hasil }\end{array}$ \\
\hline
\end{tabular}

Dilihat dalam pandangan sejarah, sistem bagi hasil yang diterapkan dalam perbankan Islam dalam bentuk mudharabah sesungguhnya merupakan suatu ciptaan yang baru sekarang ini. Bahkan bank Islam dalam pengertian sekarang, sesungguhnya tidak ada dalam sejarah peradaban Islam lama ataupun pertengahan. Sebab cara kerja bank Islam sama saja dengan cara kerja bank konvensional. Karena itu, bagi hasil yang digunakannya berbeda dari bagi-hasil pada masa Rasulullah ataupun masa kehidupan para 
pakar hukum Islam lama. Bagi hasil pada masa Islam pertama dan abad pertengahan terjadi secara perseorangan atau antar individu sedangkan bagihasil dalam bank Islam terjadi pada dua tingkat, yakni bagihasil investor dengan bank dan bagi hasil bank dengan pengusaha. Perbedan itu lebih dipengaruhi segi kelembagaan bank itu sendiri.

Adapun faktor yang mempengaruhi bagi hasil di bank syari'ah adalah kontrak mudharabah, yakni suatu kontrak yang dilakukan oleh minimal dua pihak. Tujuan utama kontrak ini adalah memperoleh hasil investasi. Besar kecilnya investasi di pengaruhi banyak faktor. Faktor pengaruh tersebut ada yang berdampak langsungdan ada yang tidaklangsung. Faktor langsung (direct factors) yang mempengaruhi perhitungan bagi hasil adalah investment rate, jumlah dana yang tersedia, dan nisbah bagi hasil (profit sharing ratio). Investmen rate merupakan prosentase aktual dana yang dapat diinvestasikan dari total dana yang terhimpun. Jika $80 \%$ dana yang terhimpun diinvestasikan, berarti $20 \%$ nya dicadangkan untuk memenuhi kebutuhan likuiditas. Jumlah dana yang tersedia untuk diinvestasikan merupakan jumlah dana dari berbagai sumber yang dapat diinvestasikan. Dana tersebut dapat dihitung dengan menggunakan salah satu metode rata-rata saldo minimum bulanan; investment rate dikalikan dengan jumlah dana yang tersedia untuk investasi akan menghasilkan jumlah dana aktual yang digunakan. Salah satu ciri al mudharafah adalah nisbah yang harus ditentukan sesuai persetujuan di awal perjanjian.Nisbah antara satu bank dengan bank lain dapat berbeda. Dan nisbah dapat berbeda dari waktu kewaktu dalam satu bank, misalnya deposito 1 bulan, 3 bulan, 6 bulan dan 12 bulan.

Sedangkan faktor tidak langsung yang mempengaruhi bagi hasil adalah penentuan butir-butir pendapatan dan biaya muddharabah. Bank dan nasabah melakukan share pendapatan yang dibagi hasilkan adalah pendapatan yang diterima dikurangi biaya-biaya. Jika semua biaya ditanggung bank, maka hal ini disebut revenue sharing. Kebijakan akunting (prinsip dan metode akutansi), bagi hasil secara tidak langsung dipengaruhi oleh jalannya aktivitas yang diterapkan, terutama dengan pengakuan pendapatan dan biaya.

\section{KETENTUAN TENTANG SISTEM BAGI HASIL DI BANK MUAMALAT CABANG KOTA JAYAPURA}

Di dalam sistem ekonomi manapun uang dan perbankan memiliki peranan penting. Bahkan ada suatu tulisan yang menyatakan "kalau kita ingin menguasai secara total perekonomian suatu bangsa maka kuasailah sistem perbankannya". Jadi antara uang dan bank merupakan dua hal penting yang tidak dapat dipisahkan dalam sistem ekonomi suatu Negara.Walaupun uang 
dan perbankan memiliki peranan penting dalam suatu ekonomi, namun untuk memainkan peranan tersebut harus didasarkan pada ajaran apa yang dianut oleh sistem ekonomi tersebut. Jika yang dijadikan pijakan adalah sistem ekonomi Islam, maka dasarnya adalah ajaran atau syari'at Islam. Oleh karena itu, hal tersebut perlu diperbaharui dan diorganisasikan dengan cara tertentu sehingga serasi dengan ethos Islam dan mampu memenuhi aspirasi umat. Apa yang harus dipenuhi untuk merealisasikan dan mendukung serta menempatkan pentingnya peranan uang dan perbankan dalam suatu sistem ekonomi secara benardan utuh. Program pembaharuan apapun yang diambil harus mengaitkannya dengan dua kandungan pokok, yaitu: tujuan yang akan dicapai dan bagaimana strategi pencapaiannya.Untuk meminimalisir problem dalam bank syari'ah pada beberapa hal untuk mengatasinya dengan mengedepankan tujuan dan fungsi yang jelas serta strategi yaitu:pertama, tujuan dan fungsi. Tujuan dan fungsi yang paling penting untuk mengenali karakteristik fundamental sistem keuangan dan perbankan Islam adalah adanya kelayakan ekonomi yang luas berlandaskan full employment dan tingkat pertumbuhan ekonomi yang optimum; keadilan sosio-ekonomi dengan pemerataan distribusi pendapatan dan kesejahteraan; stabilisasi dalam nilai uang sehingga memungkinkan medium of exchange dapat dipergunakan sebagai satuan perhitungan, patokan yang adil dalam penangguhan pembayaran, dan nilai tukar yang stabil; penagihan yang efektif dari semua jasa biasanya diharapkan dari sistem perbankan. Dari empat tujuan dan fungsi tersebut, sepintas dapat dinyatakan bahwa tujuan dan fungsi tersebut adalah yang ada dalam sistem kapitalis. Akan tetapi, kalau dikaji lebih mendalam, walaupun kelihatannya ada kesamaan, namun sesungguhnya ada perbedaan dalam penekanan. Perbedaan tersebut adalah terletak pada perbedaan komitmen kedua sistem tersebut tentang nilai-nilai spiritual, keadilan sosio-ekonomi dan persaudaraan manusia.

Di dalam Islam, tujuan yang hendak dicapai tidak dapat dipisahkan dari ideologi dan keyakinan.Tujuan merupakan masukan yang penting bagi sebagian hasil yang juristic.Tujuan membawa sanksi dan sepanjang tujuantujuan tersebut didasarkan pada Al-Qur'an dan al-sunnah, maka hal ini menjadi keharusan, bukan persoalan tawar menawar politik dan untunguntungan.Walaupun demikian hal ini merupakan strategi yang penting untuk merealisasikan tujuan-tujuan tersebut, dan disini pula Islam memberikan kontribusi yang unik.Keunikan kontribusi Islam adalah terletak pada keseluruhan tujuan dan fungsi diatas. Berkaitan dengan tujuan dan fungsi kelayakan ekonomi yang luas berlandaskan full employment dan tingkat pertumbuhan ekonomi yang optimum, maka dalam bidang ekonomi harus ditekankan pada pentingnya kelayakan ekonomi melalui pemenuhan semua kebutuhan dasar, pembebasan dari semua sebab utama yang menimbulkan 
beban berat, dan peningkatan dalam kualitas kehidupan, secara moral maupun secara material. Hal ini juga menekankan pentingnya penciptaan suatu lingkungan ekonomi yang memungkinkan khalifatullah dapat memanfaatkan dan kemampuan fisik maupun mental mereka untuk memperkaya dirinya, keluarganya dan masyarakatnya.

Berkenaan dengan tujuan dan fungsi penagihan yang efektif dari semua jasa biasanya diharapkan dari sistem perbankan. Dalam hal ini dapat ditempuh dengan dua cara, yaitu: mobilisasi tabungan dan mewujudkan jasajasa lain. Tujuan mobilisasi tabungan sangat penting karena ditujukan untuk mewujudkan tujuan-tujuan sosio-ekonomi yang dikehendaki oleh Islam.Islam dengan tegas mencela perbuatan menahan-nahan tabungan dan sekaligus menuntut digunakannya tabungan tersebutuntuk hal-hal yang produktif. Sistem mobilisasi tabungan, seharusnya bukan sekedar diperuntukkan guna memenuhi kebutuhan akan perekonomian yang sehat dan sedang tumbuh, tetapi yang lebih penting adalah harus mampu mengembangkan pasar uang primer dan sekunder, mewujudkan jasa-jasa perbankan lain bagi negara.Keberadaan pasar primer dan sekunder adalah penting bagi upaya mobilisasi sumber-sumber keuangan yang efisien.Pasar primer sebagai penyedia keuangan untuk usaha-usaha produktif, sedangkan pasar sekunder ditujukan untuk membantu penabung dan investor mencairkan investasi mereka manakala merasa perlumelakukannya.

Ada beberapa elemen penting dalam strategi Islam dalam rangka untuk memperkuat basis ekonomi umat. Pertama, bersatunya semua hal yang dianggap sebagai aspek kehidupan biasa dengan spirit untuk meningkatkan moral manusia dan masyarakat tempat dia hidup. Tanpa peningkatkan spirit semacam itu, tidak akan ada satu tujuanpun yang dapat direalisasikan dari kesejahteraan manusia yang sesungguhnya jadi sulit diwujudkan.

Kedua, bahwa Islam telah memberikan satu cetak biru (blueprint) untuk pengorganisasian seluruh aspek kehidupan, ekonomi, sosial dan politik yang memperkuat keberanian masyarakat untuk mengatakan yang benar dan mengaktualisasikan tujuan-tujuan yang sangat dekat dengan Islam. Misalnya, distribusi pendapatan dan kekayaan yang merata, tujuan-tujuan yang ingin dicapai oleh semua sistem ekonomi, tidak akan bisa dicapai tanpa adanya keyakinan mengenai persaudaraan manusia yang hanya bermakna bagi mereka yang percaya adanya Tuhan Yang Esa, dimana dihadapan-Nya semua manusia sama dan akan dimintai pertanggungjawabannya, sistem sosioekonomi yang tidak menciptakan sikap sosial berdasarkan hukum survival Darwin, melainkan mereorganisasikan masyarakat atas landasan moral untuk mendorong interaksi sosio-ekonomi atas dasar keadilan dan kerjasama, sistem sosio-politik yang mampu mencegah perlakuan tidak adil 
dan eksploitatif melalui berbagai cara termasuk mencegah riba, dan memberikan dukungan material bagi yang lemah, masyarakat dan Negara.

Ketiga, Islam mengakui kemerdekaan individu, Islam tidak menomorsatukan kekuatan pasar. Berjalannya kekuatan pasar yang buta tidak dengan sendirinya menghasilkan upaya yang produktif secara sosial, menghentikan eksploitasi atau menolong mereka yang lemah atau membutuhkan. Ini merupakan tanggung jawab negara untuk berperan positif dalam mengarahkan dan mengatur perekonomian untuk meyakinkan bahwa tujuan-tujuan syari'ah semuanya terpenuhi. Peranan positif masyarakat Islam ini tidak dapat disamakan dengan apa yang biasa dikenakan dengan intervensi dalam terminologi kapitalis. Terminologi intervensi dengan konotasi negatif, mengingatkan akan komitmen kepada laissez faire kapitalisme yang mengandungpengertian bahwa Negara yang paling baik adalah negara yang memainkan peranan paling kecil. Padahal sudah menjadi kewajiban bagi negara untuk memainkan peranan aktif dalam mencapai tujuan-tujuan sistem yang Islam tanpa mengorbankankemerdekaan individu atau berkompromi dengan kesejahteraan sosial. Dari uraian diatas jelas menunjukkan bahwa strategi bagi pembaharuan masyarakat Islam dan perekonomian memegang peranan penting.

Di sini jelas bahwa konsep Islam tidak sepenuhnya mengandalkan kekuatan pasar seperti yang ada dalam sistem kapitalisme, begitu juga tidak sepenuhnya mengandalkan pada kekuatan paksa negara seperti dalam sistem Marxisme. Individu, sebagai khalifatullah di muka bumi, secara moral diberi kewajiban untuk dapat melaksanakan peranannya benar-benar sebagai khalifah. Oleh karena sistem keuangan dan perbankan bukan merupakan bagian terpisah dari perekonomian, reorganisasinya juga harus menjadi bagian yang penting dari keseluruhan perubahan, termasuk transformasi moral, regenerasi sosio-ekonomi dan pembaharuan politik. Peran proaktif dan positif negara tidak dapat diabaikan.Ini harus diapresiasikan bahwa tujuan-tujuan Islam, di satu pihak, tidak dapat direalisasikan tanpa memungkinkan sistem keuangan dan perbankan untuk memainkan peranannya yang memadai sesuai dengan ajaran Islam. Di lain pihak, tujuan-tujuan tersebut juga tidak dapat direalisasikan hanya dengan mereorganisasikan sistem keuangan dan perbankan. Di antara elemen utama dari strategi bagi pembaharuan sistem keuangan dan perbankan (misalnya, penghapusan riba dan berbagai untung dan rugi) telah diatur oleh Al-Qur'an dan al-sunnah.

Sementara elemen-elemen lain tentu harus dirancang oleh masyarakat Islam sesuai dengan kondisi dan posisi relatif mereka dalam rangka mereaktualisasikan tujuan yang dikehendaki. Strategi yang paling adil untuk mencapai tujuantersebut adalah melalui penerapan sistem bagi hasil 
dalam operasional perbankan. Selanjutnya, problem yang terjadi dalam perbankan syari'ah, termasuk Bank Muamalat dapat diminimalisir dengan meletakkan tujuan, fungsi serta strategis yang jelas tegas jitu secara Islami.

Terhadap persepsi yang menganggap sistem bagi hasil pada bank syariah ini pada akhirnya pengembalian kredit ternyata lebih banyak bila dibandingkan dengan sistem bank konvensional harus diluruskan kembali sesuai dengan tujuan bank syari'ah.Adapun tujuan pendirian bank syari'ah menurut M. Zaini Abdad adalah peningkatkan kualitas kehidupan sosial ekonomi masyarakat muslim sehingga kesenjangan sosial di bidang ekonomi semakin berkurang; melayani masyarakat muslim secara leluasa dalam dunia perbankan yang berdasarkan syari'ah, karena bank yang ada selama ini bersifat konvensional yang operasionalnya menggunakan bunga. Sementara masyarakat muslim beranggapan bahwa bunga dalam prinsip Islam adalah riba, sedangkan riba adalah haram; meningkatkan partisipasi masyarakat banyak dalam proses pembangunan, terutama dalam bidang ekonomi keuangan; mengembangkan lembaga bank dan sistem perbankan yang sehat berdasarkan efisiensi dan keadilan, meningkatkan partisipasi masyarakat yang dapat menggalakkan usaha-usaha ekonomi rakyat; mendidik dan membimbing masyarakat untuk berpikir ekonomis serta berperilaku bisnis dan meningkatkan kualitas hidup mereka.

Jika dilihat dari segi bunga memang kecil, tetapi aspek yang lain dalam ekonomi syari'ah yaitu aspek tolong-menolong terhadap orang lain. Ini yang menjadikan esensi dari ekonomi syari'ah. Salah satu cara agar ekonomi syariah tetap berjalan dan berkembang yaitu harus menunjukkan bahwa ekonomi syari'ah merupakan sistem ekonomi yang memiliki rasa keadilan daripada sistem ekonomi kapitalis. Disamping itu ekonomi syari'ah sudah mengkultur pada masyarakat Islam di Indonesia. Sebagai misal adalah sistem bagi hasil yang dalam bahasa Jawa adalah 'paron' antara petani penggarap dengan pemilik sawah, antara pemilik ternak dengan orang yang mengurusi ternak, dan sebagainya. Sistem bagi atau paron sudah mengkultur di Indonesia sejak jaman nenek moyang kita, namun untuk menjadikan sebuah kajian internasional, orang masih banyak yang tidak begitu tertarik. Di era globalisasi ini, alangkah baiknya apabila masyarakat mengikuti arus globalisasi. Untuk itu sistem syari'ah merupakan perekonomian yang tepat untuk pertumbuhan pembangunan yang berkeadilan. Karena ternyata dengan sistem bank konvensional, bangsa Indonesia sampai saat ini terbelit dengan hutang luar negeri, dimana sistem pengembalian hutang ini disertai dengan bunga yang harus dibayarkan setiap membayar angsuran. Dan sebagaimana diketahui keruntuhan Orde Baru dikarenakan hutang luar negeri yang menumpuk akibat praktek bank konvensional. 
Dari uraian di atas yang perlu digarisbawahi dalam menghadapi hambatan tentang persepsi umat Islam untuk menerima alasan mengenai bank syari'ah dan menganggap bank syari'ah lebih ringan daripada bank konvensional adalah menyamakan persepsi agar terhindar dari riba bunga bank yang dasar hukumnya berbeda-beda menurut ulama, yaitu dengan menjauhi dari riba termasuk dalam transaksi perbankan dengan bunga dan menggunakan sistem bagi hasil yang dalam agama Islam sangat dianjurkan; adanya hitung-hitungan yang menganggap bahwa besarnya dana yang dikembalikan akan lebih besar daripada pinjaman di bank konvensional. Hal ini adalah keliru, karena hitungan bagi hasil pada bank syari'ah bersifat pasti. Apabila besarnya laba dihitung besar, maka bagi hasilnya pun juga besar dan hal ini tidak mempengaruhi pendapatan peminjam modal, karena untungnya juga tetap akan besar. Sementara kalau peminjam mengalami kerugian maka bank juga akan menerima dampaknya karena bank juga akan menanggung kerugian tersebut. Sementara bank konvensional dalam memberikan kredit dengan mengejar keuntungan berdasarkan besarnya bunga yang dibebankan kepada peminjam. Apabila peminjam tidak dapat mengembalikan modal, maka peminjam akan mengembalikan bunga secara terus menerus, padahal modalnya sudah habis dan lama kelamaan peminjam akan gulung tikar karena jaminan hutang. Untuk itulah perlunya persepsi yang benar dari sistem bagi hasil yang manfaat labanya adalah untuk keuntungan bersama, baik peminjam dan pihak bank syari'ah sebagaimana tujuan pendirian bank syari'ah tersebut.

Ada beberapa aspek penting yang perlu diperhatikan berkaitan dengan ketentuan sistem bagi hasil di Bank Muamalat. Pertama, jangka waktu berlakunya Perjanjian. Bahwa batasan waktu adalah bagian penting dari sebuah transaksi, sehingga dengan upaya mendatangkan manfaat bagi kedua belah pihak, oleh karena itu persoalan jangka waktu harus diterima berdasarkan kesepakatan dan kerelaan antara kedua belah pihak yang berserikat mudhorobah. Oleh karenanya Allah SWT berfirman dalam Q.S. Al Maidah/5: 1 yang terjemahnya: "Hai orang-orang yang beriman, penuhilah akad-akad itu".

Kedua, penarikan modal dan pembatalan perjanjian.Penarikan modal dan pembatalan perjanjian pada dasarnya boleh saja asalkan sesuai dengan kesepakatan dan tidak merugikan pihak lain. Sebab, tidak boleh ada yang dirugikan atau mendapatkan bahaya dalam kepentingannya, sebagaimana prinsip kaedah fiqih yang diambil dari teks hadits nabi yang artinya "tidak boleh membahayakan orang lain dan tidak membalas tindakan membahayakan dengan bahaya pula". Bagi mudhorib yang ingin membatalkan akad mudhorobah-nya sewaktu-waktu, sebagaimana sohibul maal dengan syarat sepengetahuan pihak mitranya untuk membatalkan akad 
dan modal berbentuk uang tunai. Apabila modal berbentuk barang maka agar ditunggusampai modal dan asset tersebut menjadi tunai, sehingga menjadi jelas keuntungan atau kerugian usaha tersebut.Karena mudhorobah pada prinsipnya adalah akad jaiz (boleh).

Ketiga, agunan atau jaminan dan penyitaan. Pada hakikatnya dibolehkan adanya agunan atau jaminan, berpijak pada al-maslahat yang mengacu kepada kebutuhan, kepentingan, kebaikan dan maslahat umum selama tidak bertentangan dengan prinsip dan dalil tegas syari'at Islam serta benar-benar membawa kepada kebaikan bersama yang tidak berdampak menyulitkan serta merugikan orang atau pihak lain secara umum. Agunan atau jaminan dari pengelola dapat disita oleh pemilik modal dalam kasus kerugian kehilangan modal yang benar-benar diakibatkan oleh faktor-faktor kesengajaan seperti penyelewengan, faktor kelalaian, faktor kecerobohan pihak mudhorib dan sebagainya. Agunan atau jaminan tersebut disita sebagai pengganti kerugian atau kehilangan modal yang harus ditanggung oleh pengelola.

Keempat, bagi hasil keuntungan. Dalam pembagian hasil keuntungan musyarokah mudhorobah, keuntungan pengelola dapat lebih besar atau sebaliknya lebih kecil daripada pemilik modal tergantung pada kesepakatan dalam akad Mudhorobah. Keuntungan yang diperoleh masing-masing pihak (sohibul maal dan mudhorib) harus dalam jumlah keuntungan tertentu. Jika keduanya telah sepakat bahwa seperempat (25\%) atau setengah (50\%) bagi mudhorib misalnya, maka hal itu sudah cukup dimengerti karena bagian sisa tentunya adalah bagian sohibul maal. Semuanya itu tergantung pada kesepakatan kedua pihak baik nisbah masing-masing sama, atau lebih besar atau lebih kecil dan harus ditepati, sebab umat Islam terikat dengan syaratsyarat yang telah mereka sepakati.

Kelima, hak kepemilikan modal dan penggunaan modal. Hak kepemilikan modal dan penggunaan modal kedudukannya adalah sejajar, tidak ada yang dilebihkan atau dikurangkan.Keuntungan tersebut menjadi milik bersama antara pemilik modal dengan pengelola, karena pemilik modal dan pengelola adalah sejajar,saling berkepentingan dan membutuhkan, maka keduanya harus berhak atas keuntungan dengan nisbah masing-masing. Sedangkan masalah penggunaan modal musyarokah mudhorobah boleh diadakan syarat-syarat atau ketentuan-ketentuan yang ditetapkan oleh pemilik modal dalam penggunaan modal mudhorobah dan mereka mewajibkan kepada pengelola untuk menempatinya selama bermanfaat bagi kepentingan syari'at dan tidak bertentangan dengan kaidah dan hukum syari'at. Karena firman Allah SWT dalam Q.S. Al-Maidah5: 1 sesuai pula dengan hadits Nabi Muhammad Saw yang intinya bahwa: "Orang-orang 
muslim terikat dengan syarat-syarat antara mereka kecuali syarat menghalalkan yang haram atau mengharamkan yang halal.

Keenam, sanksi bagi mudhorib (pengelola). Adanya sanksi bagi Mudhorib (pengelola) tergantung pada kesepakatan yang telah dibuat. Sebab hal itu termasuk dalam kesepakatan bersama yang harus dipenuhi dan ditepati, maka jika melanggar menanggung akibatnya dan menjamin kerugian yang menimpa modal atau kepentingan pemilik modal, sebab ia adalah seorang wakil dari sohibulmaal dalam menjalankan modal, maka tindakan yang terkait dengan musyarokah mudhorobah harus sesuai dengan ketentuan atau syarat yang ditetapkan oleh muwakil dalam hal ini pemilik modal.

Ketujuh, pemilik modal ikut mengelola usahanya. Pengelolaan modal adalah menjadi kewajiban dan tanggung jawab si pemiliknya mudhorib (pengelola). Dengan demikian tidak dibenarkan pemilik modal untuk mensyaratkan supaya ia memiliki hak dalam pengelolaan karena bertentangan dengan hak mudhorib dalam hal itu. Namun demikian, pemilik modal dapat mengelola modal dengan izin mudhorib, jika mudhorib tidak mengizinkan maka tidak dapat dipaksakan.

Kedelapan, pemilik modal bisa tunggal dan berserikat. Pada dasarnya pemilik modal dapat berdiri sendiri tanpa kolektif dengan pemilik model lainnya.Dalam hal ini modal orang yang bukan mudhorib merupakan mudhorobah ditangan seorang dari kalangan pemilik modal dan modal tersebut dikategorikan sebagai saham miliknya pula.

Kesembilan, perhitungan bagi hasil. Bagi hasil dalam keuntungan merupakan ciri utama bagi lembaga keuangan tanpa bunga atau disebut Bank Muamalat.Orientasi keuntungan dalam sistem perbankan merupakan salah satu tujuan usaha dalam bidang perbankan termasuk bank syariah.Bahkan acapkali bunga menjadi tolak ukur keberhasilan sebuah bank, hal ini sering dilontarkan oleh beberapa kalangan, bukan saja kalangan awam, namun masih banyak tokoh yang belum memahaminya.Bagi hasil sering orang menyebut pengganti namanya "bunga" untuk menjawab ini kita mencoba menganalisa perhitungan bagi hasil melalui ilustrasi pada pembahasan berikut ini akan memberikan gambaran ril letak perbedaan antara sistem bagi hasil dan bunga. Dalam memperhitungkan pendapatan yang akan dibagi hasilkan, bank syariah perlu juga memperhatikan suku bunga yang berlaku di luar, sehingga apabila setelah dibagikan hasilnya ternyata lebih rendah dengan suku bunga di luar, bank dapat pula membuat kebijaksanaan dengan menambah porsi pendapatan untuk nasabah, berarti kesempatan untuk bank lebih kecil lagi. Kebijakan bank ini tentu saja berakibat biaya menjadi naik. Oleh sebab itu bagi pengelola bank syari'ah 
harus berhati-hati dalam hal ini, sebab jika kondisi bank belum sehat kebijakan bank ini akan semakin memperburuk kondisi bank itu sendiri.

\section{ANALISIS PRODUKTIVITAS PENGELOLAAN ZAKAT DARI SISTEM BAGI HASIL DI BANK MUAMMALAT CABANG KOTA JAYAPURA}

Bank Muamalat Cabang Kota Jayapura melalui Baitul Maal Muamalat (BMM) dalam tiap tahunnya selalu memberikan bantuan kepada beberapa pihak, diantaranya: pembagian sembako untuk kaum dluafa dan anak yatim piatu, program SBL (Sahur Berbuka dan Lebaran) yang diberikan berupa paket sembako $300 \mathrm{rb}$ perpaket, dan paket lebaran $300 \mathrm{rb}$ peranak berupa uang tunai dan perlengkapan sholat. Program Baitul Maal Muamalat ini menyeluruh se-Indonesia. BMM juga memiliki program pembagian peralatan sekolah untuk siswa siswi di Kota Jayapura sebanyak 2090.5 Baitu Maal Muamalat merupakan kelembagan di Bank Muamalat yang memiliki tugas dan fungsi menerima sekaligus mendistribusikan zakat infak dan shodaqah dari berbagai pihak termasuk dana yang berasal dari pendapat terhadap penerapan sistem bagi hasil di Bank Muamalat.

Dalam upaya mendistribusikan bantuan atau zakatnya, Bank Muamalat melalui BMM juga bekerjasama dengan beberapa instansi, termasuk dengan Sekolah Tinggi Agama Islam (STAIN) Al Fatah Jayapura. Penyaluran zakat ini diserahkan bersamaan dengan aktifitas mahasiswa Kuliah Kerja Nyata (KKN) bersama masyarakat di Arso 7 Kabupaten Keerom. Adapun penyaluran zakat tesebut diberikan terhadap beberapa masyarakat kurang mampu sebagai bentuk implementasi zakat Bank Muamalah sebagai hasil keuntungan yang diperoleh dengan penerapa sistem bagi hasil tersebut.

Awalnya, managemen muamalat tingkat cabang dapat secara langsung mengatur mengenai besaran dan pola penyerahan bantuan kepada para pihak, namun untuk saat ini, dengan berubahnya pola managerial Bank Muamalat, kebijakan yang ada di pegang oleh kendali managemen Bank Muamalat Pusat. Dahulu, jika ada pihak atau lembaga yang mengajukan proposal bantuan, managemen Bank Muamalat di tingkat cabang tersebut memiliki otoritas untuk mengambil kebjikan, namun sekarang harus kembali ke pusat. Managemen Bank Muamalat tingkat cabang hanya sebatas memberikan rekomendasi, proposal-proposal mana yang kiranya perlu untuk di ajukan ke pusat. Untuk proposal yang tidak direkomendasi managemen Bank Muamalat di tingkat cabang, maka secara otomatis tidak

${ }^{5}$ Wawancara dengan Doddy Fabeanto (Relationship Manager financing) pada 24 Oktober 2017 di Masjid Al Hamid STAIN Al Fatah Jayapura Pukul: 14.20 wit. 
bisa di tindaklanjuti. Biasanya, permohonan yang diprioritaskan adalah permohonan yang diajukan oleh pihak masjid dan permohonan yang berupa santunan yatim piatu. Misalnya, bantuan bank muamalat untuk Masjid Fajrul Islam Kotaraja Jayapura sebesar delapan juta, Hidayatullah Kota Jayapura untuk 200 siswa berupa satu paket perlengkapan sekolah dan uang 150 ribu. Pernah juga memberikan bantuan sembako bagi masyarakat Pulau Kosong Kota Jayapura, Arso, dan Bonggo Kabupaten Sarmi. Bantuan-bantuan tersebut diberikan secara rutin tiap tahun. Di lain pihak, Bank Muamalat juga memberikan bantuan beasiswa yang biasanya di ajukan oleh para karyawan Bank Muamalat. ${ }^{6}$

Berbagai bentuk bantuan tadi disalurkan oleh salah satu kelembagaan yang ada di Bank Muamalat, yakni Baitu Maal Muamalat (BMM). Bantuan tersebut di nyatakan sebagai bentuk distribusi zakat dari para pihak yang memberikan zakat, infaq, shodaqah, dan sebagai zakat dari hasil usaha Bank Muamalat dengan penerapan sistem bagi hasil tesebut.

Hal lain yang perlu kita lakukan telaah berkaitan dengan distribusi zakat atau bantuan Bank Muamalat melalu Baitu Maal Muamalat adalah tentang pandangan Islam mengenai bentuk implementasi zakat dari Bank Muamalat tersebut. Karena sebagai sebuah kelembagaan keuangan syarai'ah yang menerapkan konsep syari'ah secara operasionalnya, dan mendapatkan keuntungan dari hasil usahanya, maka Bank Muamalat berkepentingan untuk mengeluarkan sebagian pendapatan tersebut sebagai zakatnya. Mengingat bahwa dalam Islam, zakat menduduki posisi yang sangat penting. Zakat tidak saja menjadi rukun Islam, tetapi juga menjadi indikator dan penentu apakah seseorang itu menjadi saudara seagama atau tidak. Maksudnya, bila seorang muslim telah kena wajib zakat, tetapi tidak mau berzakat, maka ia bukan lagi saudara seagama. Hal ini secara tegas dikemukakan Al-Qur'an, "Jika mereka bertaubat, mengerjakan shalat dan mengeluarkan zakat, barulah mereka menjadi saudaramu seagama". (QS.5:8).

Dengan demikian, orang yang mengabaikan kewajiban zakat, sesungguhnya telah melakukan keingkaran dan kedurhakaan besar kepada Allah. Karena itulah, ketika di masa Abu Bakar ada sebagian kaum muslimin yang mengaku muslim dan rajin shalat, tetapi enggan membayar zakat, Abu Bakar dengan nada marah mengeluarkan statemen yang artinya: Demi Allah, aku akan perangi siapa yang memisahkan shalat dengan zakat.Abdullah bin Mas'ud mengatakan bahwa barang siapa yang melaksanakan shalat, tapi enggan membayar zakat, maka tidak ada shalat baginya.Begitu eratnya keterkaitan shalat dan zakat, sehingga Ibnu Katsir mengatakan dalam tafsirnya, "amal seseorang itu tidak bermanfaat, kecuali dia menegakkan

\footnotetext{
${ }^{6}$ Wawancara dengan Maryani, S.IP., pada tanggal 10 Oktober 2017 di Kantor Bank Muamalat Cabang Jayapura.
} 
shalat dan menunaikan zakat sekaligus".Menurut Sayyid Sabiq dalam kitab fiqh al-sunnah, di dalam Al-Qur'an perintah shalat dan zakat digandengkan sampai 82 kali. Ini menunjukan bahwa shalat dan zakat tidak bisa dipisahkan dalam kegiatan amal seorang muslim. Shalat merupakan ibadah badaniyah sedangkan zakat merupakan ibadah maliyah. Shalat merupakan hubungan vertikal kepada Allah, sedangkan zakat lebih bersifat horizontal dan sosial.

Dalam rangka memotivasi dan membangun masyarakat yang taat zakat, Islam tidak hanya mengumumkan punishment (azab) yang sangat keras bagi penolakannya (QS. 9:35, 41:7) dan memberikan reward (jaza') yang sangat besar bagi yang melaksanakannya. (QS. 30:39, 9:19), lebih dari itu, berbagai credit point, termasuk garansi dicurahkannya keberkahan dan pelipatgandaan asset bagi orang-orang yang membayar zakat (QS. 267).

\section{ZAKAT DAN PEMBERANTASAN KEMISKINAN}

Islam sangat concern kepada pembangunan sosio-ekonomi rakyat (umat). Islam mempunyai perhatian yang tinggi untuk melepaskan orang miskin dan kaum dlu'afa dari kemiskinan dan keterbelakangan, tanpa harus didahului oleh gerakan revolusi kaum miskin dalam menuntut perubahan nasibnya. Perhatian Islam terhadap kaum dlu'afa tidak bersifat insidentil, tetapi reguler dan sistimatis.

Tak dapat dipungkiri bahwa zakat sangat berpotensi sebagai sebuah sarana yang efektif untuk memberdayakan ekonomi umat. Potensi itu bila digali secara optimal dari seluruh masyarakat Islam dan dikelola dengan baik dengan manajemen amanah dan profesionalisme tinggi, akan mewujudkan sejumlah dana yang besar yang bisa dimanfaatkan untuk mengatasi kemiskinan dan memberdayakan ekonomi umat. Namun, gerakan zakat yang telah dilancarkan sejak lama dan telah dikembangkan oleh banyak Badan Amil Zakat dan Lembaga Amil Zakat, belum memiliki dampak yang signifikan dalam mengentaskan kemiskinan ummat di Indonesia.Salah satu aspek penting yang harus diperhatikan adalah mengenai distribusi zakat. Banyak masyarakat (muzakki) yang tak faham tentang esensi zakat yang sebenarnya, sehingga ia telah merasa melaksanakan kewajiban zakat secara sempurna, manakala ia telah mengeluarkan zakat hartanya. Padahal persoalan zakat bukan hanya sekedar mengeluarkan zakat harta, tetapi di sana ada keperluan akan manajemen distribusi zakat yang dapat secara efektif memberantas kemiskinan. Karena itulah kita perlu merubah paradigma distribusi zakat agar dapat memberantas kemiskian dengan jauh lebih efektif daripada caracara selama ini yang banyak dilakukan oleh masyarakat. 


\section{PROBLEMATIKA DISTRIBUSI ZAKAT}

Jika kita mencermati implementasi zakat Bank Muamalat Cabang Kota Jayapura yang sebatas di wujudkan dengan bantuan sembako, peralatan sekolah, uang tunai, maka terkesan bahwa zakat yang di berikan oleh Bank Muamalat melalui kelembagaan Baitul Maal Muamalat (BMM) tersebut belum sepenuhnya memiliki orientasi produktif. Karena jika kita membicarakan tentang zakat dan sedekah, ada tiga kebiasaan yang hidup di kalangan muzzaki, mustahiq (penerima sedekah) dan amil (pekerja). Di kalanganmustahiq, tradisi berderma ternyata belum mengubah kesejahteraan fakir miskin. Hal ini menurut Eri Sudewo setidaknya disebabkan beberapa faktor. Pertama, berderma cenderung dipusatkan di Ramadhan. Berarti selama 11 bulan fakir miskin dibiarkan menderita, sedangkan di Ramadhan dipersilakan berpesta. Bersedekah pasti dapat ganjaran. Tetapi jika niatnya untuk pahala karena segala amal dilipatgandakan di Ramadhan, artinya derma itu karena Ramadhan. Padahal nishab (batas harta terkena wajib zakat) dan haul (masa satu tahun) zakat tak kenal Ramadhan. Karena ingin ke surga sendirian, tak lagi terpikir bahwa tujuan zakat adalah untuk mengubah kondisi fakir miskin. Kedua, sedekah ingin disegerakan sebelum Id Fitri. Sesungguhnya itu hanya berlaku bagi zakat fitrah. Tujuan zakat fitrah memang konsumtif, agar fakir miskin punya makanan untuk bisa berhari raya. Sementara zakat harta, zakat profesi, serta zakat perdagangan misalnya, harus dikelola untuk mengubah kondisi fakir miskin.

Ketiga, banyak muzakki ingin melihat zakatnya langsung diterima mustahiq. Semakin besar zakat harta yang dikeluarkan, makin donatur tergoda mengelola sendiri. Karena donatur tak punya waktu lebih serius agar zakat produktif, paket santunan jadi alternatif paling mudah. Saat berlangsung penyerahan santunan, terjadi pertemuan kontradiktif antara "parade kemiskinan" dengan "pameran kebajikan".

Zakat harta yang harusnya menjadi modal perubahan, tetapi nyatanya tidak, karena para mustahiq-nya tetap miskin dan tidak berubah menjadi muzakki. Untuk melepaskan umat dari belenggu kemiskinan melalui zakat, maka penyaluran zakat tidak saja digunakan untuk kebutuhan konsumtif, tetapi juga untuk kebutuhan produktif, sehingga zakat menjadi salah satu institusi ekonomi umat dengan pengembangan usaha-usaha produktif umat Islam. Menyalurkan zakat untuk kepentingan produktif, bukan berarti meniadakan penyaluran yang bersifat konsumtif, karena distribusi konsumtif itu tetap selalu dibutuhkan, seperti untuk orang jompo, cacat, biaya pengobatan fakir-miskin, dan sebagainya. Penyaluran dan penggunaan dana untuk 
keperluan produktif bisa diberikan dalam bentuk bantuan modal kepada mereka yang masih punya kemampuan bekerja dan berusaha. Tentunya, disertai pula dengan dukungan teknik dan manajemen bagi kaum ekonomi lemah, sehingga mereka bisa mandiri dan terlepas dari kemiskinan. Dengan demikian, kita tidak lagi memberikan ikan, tetapi memberikan pancing. Diharapkan pada tahun-tahun berikutnya si mustahiq tadi tidak lagi sebagai penerima zakat, tetapi telah berubah nasibnya menjadi pembayar zakat (muzakki).

Inilah yang pernah diisyaratkan Nabi Muhammad saw dalam sebuah hadits riwayat Bukhari, "Berzakatlah kalian, niscaya akan datang suatu masa, di mana seorang muzakki (pembayar zakat), membawa zakat hartanya, tetapi tidak menemukan lagi orang yang berhak menerimanya. Orang yang ditawari mengatakan: "Sekiranya anda datang tahun yang lalu, maka saya menerimanya". Sekarang saya tidak lagi dijumpai di Daulah Islamiyah yang sangat luas itu. Oleh karena kemiskinan absolut telah berhasil dihapuskan, maka distribusi zakat mengalami kesulitan, sehingga terpaksa diserahkan kepada kelompok non-muslim (muallaf) di Afrika Utara.

Sejarah mencatat keberhasilan zakat dalam mengentaskan kemiskinan. Zakat dikelola secara transparan dan rapi sejak masa Rasulullah saw sampai pada masa Ummayyah, khususnya pada masa Umar bin Abdul Aziz, bahkan pada masa Kalifah Al-Manshur, negara memiliki surplus dana Baitul Mal sebanyak 810 juta dirham, yang disimpan sebagai devisa.

Tidak bisa dipungkiri bahwa fenomena kemiskinan ada di amanamana, termasuk umat Islam di dalamnya. Tradisi mengemis kini sudah menjadi fenomena umum diberbagai daerah yang ada. Kemiskinan tak lagi jadi cermin tingkat sosial, namun telah jadi profesi. Sehingga perlunya kita sebagai umat Islam untuk memikirkan kembali tentang optimalisasi pemberdayaan harta zakat tersebut untuk kemudian mampu memberdayakan ekonomi umat.

Problem lain di tingkatan pengelola zakat adalah ketika amil sebagai pihak yang bertugas menerima sekaligus mendistribusikan zakat memiliki kemampuan yang terbatas. Tradisinya bersifat kepanitiaan dengan pengelolaan paruh waktu. Karena tak ada waktu dan terbatasnya pengetahuan zakat, kegiatan amil tak beda dengan donatur, yakni bagi-bagi santunan. Suatu contoh, ketika sebuah masjid besar yang di saatramadhan bisa menghimpun zakat hampir Rp 1 milyar. Dari laporan diketahui, setengahnya habis terpakai selama ramadhan untuk buka puasa dan santunan. Dana sebesar itu, ternyata tak bisa mengubah kondisi satu keluarga mustahiq pun. Sayangnya Lembaga Pengelola Zakat (LPZ) yang profesional, dalam kampanyenya malah bangga dengan kegiatan konsumtif, seperti buka bersama dluafa dan napi, sembari bagi-bagi sembako. 
Kita harus merubah paradigma distribusi zakat dari konsumtif oriented kepada produktif oriented, agar kemiskinan lebih efektif bisa diberantas. Bila kebiasaan konsumtif di atas berlanjut, niscaya zakat dan sedekah tak banyak pengaruhnya mengentaskan kemiskinan. Sedekah untuk konsumtif memang mulia. Hanya, jauh lebih mulia jika sedekah pun dijadikan modal untuk mengubah dluafa. Kini saatnya kita mengubah paradigma berzakat. Memaksa bekerja lebih mulia ketimbang santunan. Untuk melakukan ini, maka berzakat sebaiknya diserahkan kepada lembaga amil zakat yang amanah dan terpercaya.Esensi sedekah memang hibah yang harus diberikan kepada mustahiq dimana harta yang diberikan itu menjadi miliknya, bukan disalurkan dalam bentuk pinjaman. Tetapi dalam konteks ini ada wilayah ijtihadi. Yaitu sistem distribusi dengan qardlul hasan dan bagi hasil, sehingga lebih menjamin terciptanya lapangan kerja baru yang efektif memberantas kemiskinan. Dengan terwujudnya lapangan kerja, sedekah pun merangsang profesionalitas yang pada gilirannya juga akan membangun etos kerja. Dengan memaksa fakir miskin bekerja, kegiatan rutin bagi-bagi santunan, akan terkikis. Bila metode distribusi ini yang dilakukan, maka sabda Nabi yang menjelaskan bahwa zakat akan menghapuskan kemiskinan dapat terwujud.

\section{PENUTUP}

Uraian di atas membawa kita kepada beberapa kesimpulan, sebagai berikut:

1. Bahwa terdapat beberapa macam sistem bagi hasil (profit sharing) pada Bank Muamalat Cabang Kota Jayapura. Prinsip bagi hasil (profit sharing) merupakan karakteristik umum dan landasan dasar operasional Bank Muamalat secara keseluruhan dan merupakan prinsip dalam perbankan syari'ah yang paling banyak dipakai adalah akad utama a/-musyarakah dan al-mudharabah, sedangkan al-muzaro'ah dan al-musaqoh dipergunakan khusus untuk plantation financing atau pembiayaan oleh beberapa bank Islam.

2. Bahwa ketentuan sistem bagi hasil pada Bank Muamalat Cabang Kota Jayapura melalui Baitul Maal Muamalat (BMM) sebatas pembagian sembako untuk kaum dluafa dan anak yatim piatu, program SBL (Sahur Berbuka dan Lebaran) yang diberikan berupa paket sembako tiga ratus ribu rupiah perpaket, dan paket lebaran sebesar tiga ratus ribu rupiah peranak berupa uang tunai dan perlengkapan sholat. Hal ini dalam pandangan peneliti masih belum memuat upaya produktivitas zakat dalam rangka pemberdayaan ekonomi umat 
3. Bahwa untuk menjadikan dana zakat berorientasi produktif, maka perlunya pandangan bahwa distribusi zakat bukan sekedar pada kebutuhan konsumif, namun lebih pada paradigma produktif. Adanya pola distribusi konsumtif itu di latari oleh pandangan masyarakat bahwa berderma cenderung dipusatkan di Ramadhan, sedekah ingin disegerakan sebelum Idul Fitri, banyak muzakki ingin melihat zakatnya langsung diterima mustahiq. Semakin besar zakat harta yang dikeluarkan, makin donatur tergoda mengelola sendiri. Karena donatur tak punya waktu lebih serius agar zakat produktif, paket santunan jadi alternatif paling mudah. Saat berlangsung penyerahan santunan, terjadi pertemuan kontradiktif antara "parade kemiskinan" dengan "pameran kebajikan".

\section{UCAPAN TERIMA KASIH}

Di sampaikan terima kasih kepada Bapak Rektor IAIN Faattahul Muluk Papua (Dr. H. Idrus Alhamid, S.Ag., M.Si) yang telah memberikan bantuan terhadap penelitian ini, dan teruntuk Istriku (Yuyun Shofiaan, M.Pd.) dan anak-anakku: Naila Arwa Fatimah Az Zahra; Nizam Faiz Akbar Al Dzikra; dan Nizam Ahmad Fahmi Al Fikri yang telah memberikan motivasi kepada penulis demi terselesaikannya penelitian ini.

\section{DAFTAR PUSTAKA}

Ali, Muhammad. Penelitian Pendidian Prosedur Strategi. Bandung: Angkasa, 1987.

Arikunto, Suharsimi. Manajemen Penelitian. Jakarta: Rineka Cipta, 1998.

Bakar, Anton, Ahmad Khan Zubair. Metode Penelitian Filsafat. Yogyakarta: Kanisius, 1990.

Bank Indonsia.Perbankan Syari'ah. Jakarta: BI, 2007.

F., Kerlinger, N. Foundation and Behavior Research.Alih bahasa Simatupang Landing R., Asas-asas Penelitian Behavior.Yogyakarta: Gajah Mada University Press, 2006.

Hadjar, Ibnu.Dasar-Dasar Metodologi, Penelitian Kualitatif dalam Pendidikan. Cet. II: Jakarta: Raja Grafindo Persada, 1999.

Hamoud, Sami. Islamic Banking.London: Arabian Information, 1985.

Haron, Sudin. Prinsip dan Operasi Perbankan Islam.Kuala Lumpur: Berita Publishing Sdn Bhd, 1966.

Inoed, Amiruddin dkk. Anatomi Fqih Zakat. Yogyakarta: Pustaka Pelajar, 2005. 
J., Lexy, Moleong.Metode Penelitian Kualitatif. Cet. VIII; Bandung: Remaja Rosdakarya, 2000.

Muhammad, Justice, Taqi Usmani. The Text of the Historic judgement on Riba.Kuala Lumpur: The Other press, 2001.

Mansur, Ahmad, al-Wafa.Potensi Tabungan, Modal dan Pertumbuhan Ekonomi Dalam perspektif Ekonomi Islam. Surabaya: Program Pascasarjana IAIN Sunan Ampel Surabaya, 2003.

Preferensi Islam terhadap Penghapusan Bunga dalam Membuat Struktur Modal dan Biaya Modal dalam Sistem Keuangan Islam.Surabaya: Program Pascasarjana IAIN Sunan Ampel Surabaya, 2004.

Nasution, S. Metode Penelitian Naturalistik Kualitatif. Bandung: Tarsito, 1998.

Sadr, Kadin. Money and monetary Polities in Early Islam: Essay on Iqtisa. Nur Copr: Silver Spring, 1989.

Sugiono.Metode Penelitian Pendidikan Kualitatif, Kuantitatif, dan R\&D. Bandung: Alfabeta, 2010.

Suharman, Winarno. Dasar dan Teknik Research.Bandung: Angkasa, 1987.

Wawancara dengan Doddy Fabeanto (Relationship Manager financing) pada 24 Oktober 2017 di Masjid Al Hamid STAIN Al Fatah Jayapura Pukul: 14.20 wit.

Wawancara dengan Maryani, S.IP., pada tanggal 10 Oktober 2017 di Kantor Bank Muamalat Cabang Jayapura. 
164 | Eko Siswanto

Halaman ini sengaja dikosongkan 